\title{
Birbirinin Yerine Kullanılan İki Farklı Kavram: Sekülerleşme ve Laiklik
}

\author{
Two Different Terms That Used Interchangebly: Secularization \\ and Laicité
}

\section{Volkan Ertit}

\section{Özet}

Sekülerleşme kavramı özellikle Cermen dillerindeki akademik eserlerde ve bu dillerin konuşulduğu günlük yaşamda sıkça kullanılmaktadır. Ancak söz konusu Türkiye olduğunda hem tarihsel hem de etimolojik sebeplerden dolayı sekülerleşme kavramı yeterince bilinmemektedir. Medya ve akademi dünyası, sekülerleşme kavramının ifade ettiği şeyleri laik, laiklik ve laikleşme gibi kavramları kullanılarak ifade etmektedir. Bu çalışma ise belli bir zaman dilimi içerisinde dinin toplumsal gücünün ve prestijinin azalması demek olan sekülerleşme kavramı ile siyasi bir ilke ve proje olarak devlet işleri ile dinin birbirinden ayrılması demek olan laiklik kavramı arasındaki farkı tarihsel ve etimolojik olarak ortaya koymaktır. Türkiye'de din-toplum ekseninde yapılan tartışmaların "laiklik-muhafazakârlık" ekseninden çıkması gerektiğini ifade eden makale, laik devletlerin seküler olmayan toplumları ya da laik olmayan devletlerin seküler toplumları olabileceği sonucuna ulaşmaktadır.

Anahtar Kelimeler: Sekülerleşme, Laiklik, Din, Türkiye

\footnotetext{
Arş. Gör., Aksaray Üniversitesi, Fen Edebiyat Fakültesi, Sosyoloji Bölümü volkanertit@gmail.com

Makalenin yayım aşamasına gelmesi sürecinde değerli eleştiri ve önerileri için Erasmus Üniversitesi'nden Merih Cibiş’e ve Karadeniz Teknik Üniversitesi'nden Mete Kurtoğlu'na çok teşekkür ederim.
}

Bu makale iThenticate sistemi tarafından taranmıştır. 


\begin{abstract}
The term secularization is used frequently in academic works and daily life of countries in which Germanic languages are spoken. However, when it comes to Turkey, because of the historical and etymological reasons, the concept has not gained the attention that it deserves. Turkish academics and media have preferred to use the terms of laic, laicite or laicization to express what the term secularization asserts. Therefore, the first aim of this article is to indicate and explain how the concept of secularization and the concept of laicization are different from each other. The second aim of the article is to contribute the discussions on these issues by emancipating those discussions from the axis of "laicization-conservatism" dichotomy.
\end{abstract}

Keywords: Secularization, Laicization, Religion, Turkey. 


\section{Giriş}

Sekülerleşme kavramı Türkiye kamuoyunda her geçen gün daha sık kullanılıyor olsa da, kavramla ilgili iki sorun halen güncelliklerini korumaktadırlar. Birinci sorun, din-toplum arasındaki ilişkiyi açıklamak için kullanılan sekülerleşme kavramının Türkiye'de yaşanan toplumsal dönüşümden dolayı kendisine oldukça sık yer bulacakken, ciddi bir çoğunluk tarafından neredeyse hiç kullanılmamasıdır. İkinci sorun ise laiklik kavramı ile aynı anlamı taşımamasına rağmen sekülerleşme kelimesinin laik kelimesinden türeyen kelimeler ile aynı anlama gelecek şekilde kullanılmasıdır. Özellikle akademi dünyası ve buna paralel olarak yazılı ve görsel basın bu iki kavramı birbirlerinin yerine sıklıkla kullanmaktadırlar.

O nedenle bu makalede öncelikle sekülerleşme ve laiklik kavramlarının ne olduğu tarihsel perspektiften yola çıkılarak anlatılacaktır. Kavramları netleştirdikten sonra iki kavram arasındaki farklılıklar tartışılacaktır. Ardından bu iki kavramın hem akademi dünyasında hem de medyada birbirlerinin yerine kullanıldı̆̆ı gösterilecektir. Son bölümde ise laik devletler ile dindar toplumların, ya da laik olmayan devletler ile seküler toplumların aynı anda var olabileceği farklı coğrafyalardan örnekler ile gösterilecektir.

\section{Sekülerleşme}

Sekülerleşme, belli bir zaman dilimi içerisinde, dinin, dinimsi ${ }^{l}$ mekanizmaların ve batıl inançların (doğaüstücülük ya da halk inançları) toplumsal düzeydeki prestijlerinin ve topluma etki etme güçlerinin göreceli ${ }^{2}$ olarak azalması demektir (Ertit, 2013). Sekülerleşme kelimesi etimolojik olarak Orta Çağ Latincesindeki saeculum'a dayanıyor ve günümüze kadar üç farklı anlamda kullanılıyor (Casanova, 1994). Birinci kullanım, "yüzyıl, çăg, dünya" anlamında, Roman dillerinde de secolo (İtalyanca), siglo (İspanyolca), ve siécle (Fransızca) gibi kar-

1 Seküler alanın da kutsallaştırılması, ululaştırılması, yüceleştirilmesi, doğaüstü meziyetler kazandırılması ile ortaya çıkan yapı (V.E.).

2 Tanımdaki "görece" kelimesi mutlak bir ifadenin önüne geçmek için kullanılmıştır. Sekülerleşme, belli bir toplumdaki dinin etkisinin "eskiye" nazaran "az" ya da "çok" azalmış olmasıdır. O nedenle oldukça dindar bir toplum için dahi eski ile kıyaslandığında “daha seküler" ifadesi kullanılabilir. 
Ş1lı̆g 1 olan bir kullanımdır. İkinci kullanımı kilise hukuku içerisinde manastır hayatını bırakıp "dünya"ya yönelen din adamları için kullanılan secular kelimesidir. Manastır içine kapanarak dünya ile ilişkisini kesen, inzivaya çekilmiş diğer radikal din adamlarından farklı olarak bu seküler din adamları dünya ile ilişkilerini sürdürürlerdi. Halk ile diyalog halinde, toplumun gündelik sorunlarına din perspektifinden yaklaşarak çözümler üretmeye çalışırlardı. Üçüncü kullanım alanı ise tarihsel bir süreç içerisinde dinin toplumsal alanlarda referans noktası olduğu zaman dilimlerinin azalmasını ifade etmektedir.

15. ve 19. yüzyıllar arasında Avrupa'da ortaya çıkan yedi fark11 dinamik Avrupa toplumlarının günlük yaşam pratiklerinde radikal değişimlerin ortaya çıkmasına neden oldu: Rönesans, Reformasyon, mutlak monarşilerin ortaya çıkışı, Bilimsel Devrim, Aydınlanma Çağı, endüstriyel kapitalizm ve kentleşme. Bu dinamiklerden üç tanesi -her ne kadar Avrupa merkezli olsalar da- daha sonra dünyanın en ücra köşelerinde, Hristiyan olmayan toplumlarda dahi gözlemlenecek kadar yaygınlaştılar ve benzer etkiler yarattılar: Bilimsel gelişmeler, endüstriyel kapitalizm ve kentleşme. Bilimsel gelişmelerin sekülerleşmeye etkisi iki şekilde gerçekleşmektedir. Birinci etki doğanın gizemleri için metafiziksel açıklamaların yavaşça terk edilmesidir. Örneğin eskiden güneş tutulmaları tanrıların bir mesajı olarak algılanıyor ve zaman zaman savaşların bitmesine sebep oluyorlard1. Ancak günümüzde güneş tutulmaları ruhani herhangi bir mesaj taşımayan teknik bir konu olarak hayatımızda yer almaktadırlar. Bilimsel gelişmelerin sekülerleşmeye ikinci etkisi ise gelişen teknolojik olanaklar ile daha önce zorlu koşullar altında yüce bir varlığa sığınılan günlük yaşam pratiklerinin sayısının göreceli olarak azalmasıdır.

Endüstriyel kapitalizm ile birlikte organik ve hiyerarşik olan geleneksel toplum dönüşmek zorunda kaldı. Sadece daha fazla kâr için motive olmak, özel mülkiyet hakk1, insan arzu ve isteklerinin şeytani olarak görülmesinden vazgeçilmesi, rekabet ve serbest piyasa ekonomisi, geniş kitleler için üretim yapan fabrikaların kurulması dinle yoğrulmuş dışa kapalı olan feodal sistemin çözülmesine neden oldu. Kapitalizmin ahlâkı, öbür dünya üzerine kurulu olan ve yaşadığımız dünyayı geçici gören dinlerin etkisi altındaki geleneksel toplum yapısı ile uyuşmadığından (Weber, 2001; Mises, 1981), bu süreç, kapitalizm 
öncesi toplumsal düşüncelerin, inanç sistemlerinin ve eski değer yargılarının şekil değiştirmesine neden oldu. Kitleler için üretim yapan devasa fabrikalar, iş bölümü, makineleşme, ekonomik kalkınma, servis sektöründeki artış, eğitim seviyesinin yükselmesi, ortalama yaşam süresindeki artış, bebek ölüm oranlarında azalış, sağlık giderlerinde azalış, genel kitle iletişim araçlarının yaygınlaşması ile iletişimin kolaylaşması ve hızlanması, geleneksel aile yapısında değişiklik ve daha demokratik bir yönetim şekli endüstrileşme ile toplumların yaşamına girmiş ve onların din ile kurdukları ilişkinin değişmesine neden olmuştur.

Sekülerleşme sürecinin bir diğer önemli ayağı ise kentleşme olgusudur. Kentleşme süreci ile birlikte farklı geçmişlere sahip bireyler kırsaldaki homojen yapının parçası olmaktan ayrılarak, kentte oldukça heterojen bir toplumsal yapının parçası haline gelirler. Cox (1965: 1820 )'un ifade ettiğgi gibi kentte dini inançlar, etnik aidiyetler, gelenek ve görenekler kırsala nazaran daha az önem taşırlar. Kentte dini inançlardan bağımsız olarak önemli olan bireylerin yüklendikleri fonksiyonu (doktor, avukat, kasiyer, banka memuru, elektrik teknisyeni, dolmuş şoförü v.b.) yerine getirip getirmedikleridir. Kentleşme ile beraber geleneksel ahlaki yaptırımların yerini farklı dini kültürlerden gelenleri bir arada tutabilen hukuk yasaları alır. Buna ek olarak, kentteki yeni iş alanları ve şehrin beraberinde getirdiği sosyalleşme imkânları dini faaliyetlerin ve din için ayrılan zamanın da azalmasına neden olur (Aquaviva, 1960: 212).

Modernleşme süreci ile beraber, toplumlar gündelik sorunlarına din haricinde çözüm bulabileceklerini gördüler. Bruce (1999: 266)'un vurguladığı gibi özellikle Orta Çağ boyunca Avrupa'da bilim, sanat, felsefe, sağlık ve eğitimde baskın bir güç ve ifade aracı olan din, modernleşme ile birlikte, -yani kırsalın şehre göçüşü, feodal kültüre sahip dışa kapalı küçük toplulukların farklı yaşamları içine alan toplumlara dönüşmesi, bireyciliğin yükselmesi, daha demokratik ve eşitlikçi bir yapının yaygınlaşması ve toplumsal kurumların rasyonelleşmesi iletoplumsal alanda güç kaybetti. Bu dönüşüm, yani modernleşmenin din için sorunlu alanlar yaratması, dini kurumların, dini düşünüş şeklinin ve dini pratiklerin toplum üzerindeki gücünü azaltarak, dini tüketim toplumunda bir başka tüketilecek eşyaya indirgedi (Wilson, 1979: 277; 
Hanson, 1997: 172-74). O nedenle sekülerleşme sürecinin içine, yapısal farklılaşma adı altında dini kurumların güç kaybetmesi (Bruce, 2003: 251; Lechner, 1991: 1104), geleneksel din kurallarının, ritüellerinin ve sembollerinin ortaya çıkan yeni yapı ile toplumsal düzeyde geri planda kalması (Herberg, 1962: 148), kutsal yapıların kutsallık derecelerinin sorgulanmaya başlanması, gelenekçiliğin çözülmesi, bilimin metafizikten arınması ve öbür dünya nimetleri yerine bu dünyanın imkânlarına olan eğilimin artması (Fenn, 1969:112) dâhil edilebilir.

Ancak sekülerleşme adı ile ifade edilen bu değişimler dinsizleşmek ya da inançsızlaşmak anlamına gelmemektedir. Aksine, sekülerleşme süreci din inancındaki artış ya da azalıştan bahsetmemektedir. Toplumdaki inançlı insan sayısındaki artış-azalış sekülerleşme kavramının içinde olduğu tartışmalarda doğrudan yer almamaktadır. Bir birey oldukça seküler bir hayat yaşarken de -yani günlük yaşam pratiklerine din hiç nüfuz etmese bile - halen dine ve yaratıcıya inanabilir. Keza Davie (1990, 455; 1994: 5) bu süreci believing without belonging ${ }^{3}$ olarak tanımlıyor. Sekülerleşme kavramı için önemli olan dine inanan ya da inanmayan kişi sayısındaki değişimler değil, dinin günlük toplumsal yaşayışa etki etme gücüdür.

Makalenin bundan sonraki bölümünde aynen sekülerleşme kavramının değerlendirildiği gibi, laiklik kavramı etimolojik ve tarihsel olarak değerlendirilecektir.

\section{Laiklik}

Laik kelimesi Latincede din işleriyle ilgisi olmayan anlamındaki laicus kelimesi ile Yunancadaki "halktan olan" anlamındaki laikos kelimelerinden türemiştir (Küçük, 2011: 46). Din-toplum arasındaki inişliçıkışlı ilişkiyi açıklamak için kullanılan sekülerleşme kavramına karşın laiklik din ile devlet arasındaki ilişkiye dair bir siyasi ilke ve projedir. En geniş anlamı ile laiklik, din ve devlet işlerinin birbirinden ayrılması, devletin her inanç grubuna aynı uzaklıkta olması, devletin kontrolünde olan eğitim, sağlık, güvenlik, hukuk, ekonomi gibi alanlarda herhangi bir dini grubun söz sahibi olmaması, devletin dış ve iç politika için

3 Dinin emir ve yasaklarına uymayarak, ritüellerini yerine getirmeyerek halen inançlı olma durumu. 
alınan kararlarda belli bir inanç grubunun çıkarlarını gözetmemesi, hiç kimsenin bağlı olduğu dini inançtan dolayı devlet kadrolarından uzaklaştırılmaması ya da bürokraside yükseltilmemesi, yani kısacası devletin tüm inanç gruplarına eşit mesafede olması demektir. Bu tanım laik devletin dine düşman olduğu, vatandaşlarının ibadet etme hakkını gasp edeceği, vatandaşlarını dinsizleştirmeye çalışacağı ya da dini kendi kontrolü altına alacağı anlamına gelmemektedir. Laiklik, söz konusu devlet işleri olduğunda dinin hiçbir şekilde referans noktası olarak kabul görmemesi anlamı taşımaktadır.

Günümüzde laiklik ilkesinden bahsederken özellikle iki sebepten dolayı sadece tanım vermek kimi zaman yeterli olmamaktadır. Birinci neden tarihsel, ikincisi ise etimolojiktir. Şimdi sırası ile bu iki nedeni detaylı şekilde inceleyelim.

Tarihsel olarak, 1789 Fransız Devrimi ve 1923 Kemalist Devrimi laiklik için yukarıda ifade edilenlerden farklı bir laiklik deneyimi yaşanmasına neden oldular. Hem Fransa'da hem Türkiye'de laiklik yukarıda ifade edildiği gibi sadece din ve devlet ayrımını değil, aynı zamanda devletin din üzerindeki hegemonyasını da ifade eder hale geldi. Türkçeye laiklik olarak giren kelime Fransızcadaki laïcité kelimesidir. Fransız Devrimi yaşandıktan sonra, devrimi gerçekleştirenlerin bir amacı da insanların dine değil devlete tapmalarını sağlamaktı. Esas amaç din ve devleti birbirinden ayırmak değil, dini yok etmek, yok olmayacaksa da onu devletin hegemonyasından çıkamayacağı bir duruma geriletmek idi. Devrim gerçekleştikten hemen sonra eski rejimin iş birlikçisi olarak görülen din adamları ve onlara yardım yataklık edenler vurularak, asılarak, vücutlarının bir bölümü sakat bırakılarak ve hatta baltalar ile parça parça edilerek cezalandırıldılar (Souvay, 1923: 489). Kiliseler yıkıldı, dinsel tüm semboller yok edildi. Din adamları eski rejim sırasında sahip oldukları tüm hakları kaybettiler. Devrimle ortaya çıkan yeni rejime bağlılık yemini etmeyen din adamları ölümle tehdit edildi. Devrim kanunları bir din, devrimi gerçekleştirenler de yeni totaliter peygamberler haline geldiler (Brunner, 1991: 76). Kisacası Fransız devrimcileri laicité adı altında tanımda belirtildiği gibi din ve devlet işlerini birbirinden ayırmadılar, direk dini yok etmek istediler ve yerine devleti koymaya çalıştılar. 
Fransız düşünce sisteminden ve devlet yapısından etkilenen Mustafa Kemal Atatürk ile genç Cumhuriyet'in kültürel ve siyasi etkinliğe sahip entelektüelleri 1923'te kurdukları ülke için Fransız tarzı bir yapı benimsediler. Fransız jakobenizmini ölçü alan merkezi bir yapı ile Türk toplumunu mühendis gibi yeniden dizayn etmek istediler. Fransızlar nasıl ki laicité adı altında dini yok etmek istedi ise Atatürk de yaratmak istediği yeni devlet ve toplumda laiklik adı altında din ve devlet işlerini birbirinden ayırmaktan çok, dini sembolleri hayattan uzaklaştırmak ve dini olan her şeyi devlet kontrolü altına almak istedi. 1938'e kadar 15 yıllık iktidarı döneminde Türk toplumunu dönemin çağdaş toplumlarına yakınlaştırmak için İslami sembolleri ya değiştirdi ya da ortadan kaldırdı. Amacı sadece laik bir devlet kurmak değil, aynı zamanda seküler bir toplum yaratmak idi. Hem devleti laikleştirmek hem de dinin günlük hayatta topluma nüfuz etmesini önlemek için (sekülerleşme) radikal kanunlar çıkardı. Henüz 1922 yılında Ankara Hükümeti ${ }^{4}$ tarafından padişahlığın kaldırılması belki de genç Cumhuriyet'in laikleşme yolunda ilk adımı idi denilebilir. Ardından din adamlarının dini kıyafetlerini ibadethaneleri haricinde giymeleri yasaklandı. 1924 yılında halifelik ve şeyhülislamlık (Şeriye ve Evkaf Vekaleti) kaldırıld. Medrese ve mektep ayrımı ortadan kaldırılarak laik bir eğitim sistemine geçildi. Ders müfredatları dini bilgilerden arındırıldı ve Avrupalı uzmanlara daha fazla görevler verildi. 1925 yılında tekke, zaviye ve türbeler kapatıldı. 1926 yılında İsviçre Medeni Kanunu, İtalyan Ceza Yasası ve Alman Ticaret Hukuku yeni Cumhuriyet'in dinden bağımsız olan yasalarını oluşturdular. Nasıl ki Fransız devrimcileri pazar günü ibadet edilmesin diye haftayı 7 günden 10 güne çıkardılar ve pazar kelimesini yasakladılar ise, buna benzer şekilde Atatürk de cuma olan hafta sonu tatilini pazar günü olarak değiştirdi. 1928 yılında anayasadan "devletin dini İslam'dır” cümlesi çıkartıldı. Belki de devletin laikleşme sürecinin en sert değişimi ise aynı yılın Kasım ayında yaşandı. Arap harfleri Latin harfler ile değiştirildi ve bir gecede neredeyse tüm ulus sıfırdan yazı dilini öğrenmek zorunda kaldı. 1932 yılında Türkçenin saflaştırılması adı altında Arapça ve Farsça kelimeler sözlük-

41922 yılında o zamanki Türkiye topraklarında iki hükümet vardı. Ankara Hükümeti Atatürk ve arkadaşları tarafından kurulmuştu. İstanbul Hükümeti ise eski rejim destekçilerinin kurduğu hükümet idi. 
ten çıkartıldı (Stirling, 1958: 399-403). Göle (1997: 50)' ye göre tüm bu çabaların altında Türk toplumunun Kur'an-1 Kerim ve diğer Arap harfleri ile yazılan dini kaynaklar ile ilişkisini kesmek idi. 1933 yılına gelindiğinde dini eğitim veren tüm kurumlar kapatılarak, ilkokullardaki din eğitimi yasaklandı (Stirling, 1958: 396). 1930 yılında yerel seçimler için seçme hakkı verilen kadınlar, 1934 yılına gelindiğinde genel seçimler için seçme ve seçilme hakkı aldılar. 1937 yılında ise laiklik anayasaya girdi. Böylece padişahlık ve halifeliğin kaldırılması ile başlayan ${ }^{5}$ süreç, eğitim, hukuk, ticaret, siyaset gibi alanlarda gerçekleştirilen devrimsel kararlar ile 1937 yılında laiklik ilkesinin devletin anayasasına girmesi ile resmileşmiş oldu. Fransız devrimcileri nasıl ki yeni Cumhuriyeti eski rejimin tüm kalıntılarını silerek kuracaklarını düşündülerse ve laicité uygulamasını da buna uygun gerçekleştirdiler ise, Türk devrimciler de laiklik ilkesi ile dini kamusal alandan çıkartıp eve hapsetmeye ve onu devaml kontrol edebilecekleri bir konuma indirgemeye çalıştılar.

Laiklik kavramının tanımı ile ilgili ikinci sorunun etimolojik olduğu vurgulanmıştı. Cermen dillerini (İngilizce, Almanca, Flemenkçe, Danca v.b.) kullanan halklar din ve devlet ayrımını ifade etmek için laiklik kelimesini kullanmazlar. Cermen dillerinde din ve devlet ayrımı sekülerizm kelimesi ile ifade edilir. Sekülerizm, seküler yaşam tarzını ve seküler bir devlet sistemini olumlayan ideolojinin ismidir. Bir siyasi duruş olan sekülerizm, bir sürecin ismi olan sekülerleşmeden oldukça farklıdır. Cermen dillerine mensup biri tarafından eğer laicité kavramı kullanılacaksa onun muhakkak Fransa'da radikal şekilde ayrılmış kilise ve devlet ilişkisi için olduğu vurgusu yapılır. Zira Cermen dillerinin kullanıldığ gazetelerde ve günlük hayatta laicité kelimesinden türemiş kelimeler kullanılmamaktadır. Latin kökenli olan Fransızcadaki laïcité, Cermen kökenli İngilizcede secularism, Almancada säkularismus, Danca ve Norveççede sekularisme, Flemenkçede secularismedir.

5 Türkiye'nin modernleşme süreci Osmanlı Devleti'nin modernleşme sürecinden, yani 18. ve 19. yüzyıllarda gerçekleşen reformlardan bağımsız düşünülemez. O nedenle Atatürk'ün Batı'ya benzeterek kurmaya çalıştığı yeni ülkenin köklerinin 18. ve 19 . yüzyılda askeri anlamda yapılan reformlarda, 1839 Tanzimat Fermanı'nda, 1856 Islahat Fermanı'nda ve diğer eğitim, hukuk ve ekonomideki düzenleyici kanunlarda temellerinin atıldığını ifade etmek abartılı olmayacaktır. 
Türkiye ve Fransa laiklik ile yönetilirken, devletin başının kilisenin de başı olduğu, devletin resmi bir dine sahip olduğu İngiltere, Danimarka, İsveç (2000 yılına kadar), Norveç gibi ülkeler laik değillerdir ama sekülerizm ile yönetilirler. Devletin temsili de olsa bir dini olduğu için laik değillerdir, ama devletin her inanç grubuna aynı uzaklıkta olduğu, hiç kimsenin bağlı olduğu dini inançtan dolayı devlet kadrolarından uzaklaştırılmaması ya da bürokraside yükseltilmemesi sekülerizm ile yönetildiklerini gösterir. Nasıl ki monarşiye sahipler ama parlamenter sistem ile yönetiliyorlarsa, aynı şekilde, laik bir sisteme sahip değiller -devletin dini olduğu için- ama sekülerizm ile yönetiliyorlar. Bu etimolojik farklılığı ve karışıklığı ortadan kaldırmak için Kuru (2007) “dışlayıcı" ve "pasif” kelimelerini kullanıyor. İngilizce makalesinin ismi "Passive and Assertive Secularism" iken Türkçeye bu "Dışlayıcı ve Pasif Laiklik" olarak çevriliyor. Mohanty (1989) ise yaşanan farklı sekülerizm yapıları için "hegemonik sekülarizm" ve “demokratik sekülerizm” kavramlarını kullanıyor.

Bu durumda en başta laiklik olarak ortaya konan tanımı "demokratik laiklik veya demokratik sekülerizm" şeklinde, ya da "pasif laiklik veya pasif sekülerizm" şeklinde ifade etmek daha açıklayıcı olacaktır. Kuru ve Mohanty'e göre Türkiye ve Fransa gibi ülkeler dışlayıcı ya da hegemonik sekülerizm (laiklik) ile yönetilirken, Batı Avrupa ülkeleri pasif ya da demokratik sekülerizm (laiklik) ile yönetiliyorlar diyebiliriz.

\section{Sekülerleşme ve Laiklik Arasındaki Fark}

Din ve devlet işlerinin birbirinden ayrılmasını ifade eden laiklik ile dinin toplumsal düzeyde prestij kaybettiğini, geçmişe nazaran daha az sayıda insanı etkileyebildiğini, git gide toplum için referans noktası olmaktan uzaklaştığını ifade eden sekülerleşme kavramı birbirlerinin yerine kullanılmaması gereken kavramlardır. Özden (2005)' in belirttiği gibi:

"Laiklik belli bir toplumda bir inanç, bilgi ve davranış referansı olarak dinin yaygın olup olmamasıyla ilgili değildir. Hâlbuki sekülerlik bir toplumda dinin yaygın olup olmamasıyla ve dinin referans alınıp alınmamasıyla ilgilidir. (...) Bu nedenle laikliğin kural koyuculuğu bireysel 
alanı ilgilendirmez. Yani laiklik siyasal toplumsal alanı sekülerlik ise bireysel alanı kendisine konu edinir" (18).

Karakaş (2007: 7) sekülerlik ve laiklik arasındaki farkı anlatırken Almanya, Hollanda ve Büyük Britanya örneklerini veriyor. Karakaş'a göre bu üç ülkenin seküler hukuk sistemine sahip olmaları onların laik oldukları anlamına gelmiyor. Zira Karakaş'a göre laiklik din sınıfına karşı olan bir dünya görüşüdür. Sekülerleşme ise bir görüş değildir, belli bir zaman ve mekân içerisinde din ve toplum arasındaki ilişkiyi açıklayan bir kavramdır.

Türkiye tarzı laiklik ilkesini benimseyenler, Başdemir (2011: 147)'in ifadesi ile "dinî inanç ve pratiklerin toplumsal hayatta, siyasette veya kamuda görünür durumda olmasını laiklik karşıtı durum olarak" görürler. Sekülerlik ise sadece bireyin kendine dair bir durumun ifadesidir. Yani, Türkiye ya da Fransa'daki laiklik savunucuları özellikle devlet başta olmak üzere toplumsal hayat içindeki birçok değeri dinden uzaklaştırmak isterken ve bunun mücadelesini verirken, aksine sekülerleşme kavramının toplumu dönüştürme, değiştirme, bir şeyleri yasaklama, bir şeyleri zorlama gibi ayakları yoktur. Zira sekülerleşme bir sürecin adıdır ve toplumdan ya da devletten herhangi bir beklentisi yoktur. O sadece var olan bir dönüşümün adı olarak kullanılmaktadır. O nedenle sekülerleşme kavramının ilerici ve sekülerist olmadığı ifade edilebilir. Laiklik devlet katında var olması istenilen bir dönüşümü ifade ederken, sekülerleşme (ya da desekülerleşme) hali hazırda var olan toplumsal dönüşümün adı olarak kullanılmaktadır. Laiklik siyasal-hukuki bir ilke olarak varlığını sürdürürken, henüz 1966 yılında Wilson sekülerleşmenin bir ideoloji olmadığını, sekülerleşmenin dinin geçirdiği dönüşümü alkışlamak ya da kınamak gibi bir misyonu olmadığını ifade etmişti (Wilson, 1969). Başdemir (2011)'in laiklik ve sekülerleşme arasındaki farkı oldukça açık şekilde özetlediği aşağıdaki cümleleri bu noktada oldukça toparlayıcı olacaktır:

"Türk tipi laikliğin aydınlanma ve çağdaşlaşma projesi olarak uygulanması din özgürlüğü açısından başka bir sorunu daha ortaya çıkarmıştır. Laiklik, hayatın tüm alanlarını kapsayan ve dini hayata alternatif bir yaşam biçimi olarak uygulanmıştır. Temelde hukuki ve siyasal bir dü- 
şünce ve değer olan laiklik, (...) bireylerin ve toplumun din ile olan ilişkilerindeki bireysel dönüşümleriyle ilgili olan sekülerleşme sorunuyla özdeşleşmiştir. Sekülerleşme, bireylerin dini inançlar konusundaki kendi varoluşsal durumları ile ilgilidir. Bireyler, dinin örgütlediği bir hayat biçimini kabul veya ret arasında varoluşsal bir tercihle karşı karşıya kalabilirler ve hayatlarında dinin ne oranda etkili olacağına kendileri karar verebilirler. ...sekülerleşme, [laiklik gibi] hukukî ve siyasal bir düşünce değildir” (148).

Kısacası, sekülerleşme Türkiye ve Fransa'daki laiklik anlayışı gibi topluma zorla empoze edilebilecek bir siyasi doktrin olmaktan uzaktır. Aksine, kendi iç dinamikleri olan, kendiliğinden ortaya ç1kan, ortaya çıtıktan sonra da geri dönüşü olmayan bir süreci tarif etmektedir. Birbirinden farklı şeyleri ifade eden sekülerleşme ve laiklik kavramlarının Türkiye'deki medya ve akademi dünyasında nasıl aynı anlama gelecek şekilde kullanıldığı aşağıda örnekleri ile gösterilmiştir.

\section{Birbiri Yerine Kullanılan İki Farklı Kavram}

Fransa devrimcilerinin yeni bir sistem kurarken kullandıkları laicitéyi 1923 'te yeni bir devlet kurarken kullanan, ardından bu ilkeyi anayasasına sokan bir ülkede laiklik kelimesinin seküler kelimesinden türeyen kavramlardan çok daha sık kullanılması muhakkak ki normal karşılanmalıdır. Ancak, Türkiye'deki esas sorun hangi kavramın daha az ya da daha çok kullanılıyor olması değil, bir kavramın diğerini de içine alacak şekilde kullanılıyor olmasıdır. Bu yanlış kullanımın iki ayağı vardır: Akademi ve -ona paralel olarak- medya. Ya hitap ettikleri geniş halk yığınlarının anlamayacağını düşündüklerinden, ya da henüz kendileri de kavrama çok aşina olmadıklarından Türkiye'deki kimi akademisyenler, köşe yazarları ve bazı gazete editörleri uzun zamandır laik, laiklik, laikleşme gibi kelimeleri seküler, sekülerlik, sekülerleşme gibi kelimelerin yerine kullanmaktalar. Zira farklı ortamlarda sekülerleşme kavramını anlatmaya çalışırken "yani laiklik mi" diye soru sorunların sayısının azımsanmayacak derece çok olması tesadüf gibi görünmemektedir. 
Örneğin, İnce (2012, 4 Mart) Hürriyet gazetesindeki köşesinde "toplumsal kültür laikleşmiştir" ya da "bireyin laikleşmesi" gibi ifadelere yer vermişti. Hâlbuki toplumsal kültürün laikleşmesinden çok sekülerleşmesinden bahsedilmesi daha doğru bir ifade olarak görünmektedir. Bununla beraber İnce'nin ifade ettiğinin aksine bireylerin değil, devletlerin laikleştiğinden bahsedilir. Eğer bireylerin geçmişe nazaran dinden uzak bir hayat yaşadıkları ifade edilmek isteniyorsa, onların laikleştiğinden değil sekülerleştiğinden bahsedilebilir. Mert (2009, 23 Mart), muhafazakârların zenginleştikçe dinden uzaklaştıkları iddiası üzerine kaleme aldığı bir köşe yazısına "Zenginleştikçe Laikleşiyorlar mı?" başlığını uygun görmüştü. Yazının içinde sekülerleşme kelimesi kullanılmadığı için, yazı Mert'in ifade etmek istediklerinden farklı anlamlara gelecek birçok cümle barındırıyordu. Armağan (1997, 26 Eylül) sekülerleşme tezini eleştiren yazısı için "Sekülarizasyon (Laikleşme)Efsanesi” başlı̆̆ını kullanmıştı. Yazar Armağan, muhtemelen geniş kitlelerin sekülarizasyon kelimesinden ürkmemesi için parantez içinde "(Laikleşme)" demeyi uygun görüyor.

Türkiye'de köşe yazarları ile beraber gazetelerin editöryel tercihleri de sekülerleşme kelimesini kullanmamaktan yanadır. Türkiye'de "laik-laiklik-laikleşme" gibi kelimeler sıklıkla "seküler-sekülerliksekülerleşme” kelimeleri yerine kullanılmaktadır. Türkiye'deki Zaman, Hürriyet, Milliyet ve Sabah gibi dört büyük kitle gazetesinin bu kavramları kullanma sıklıklarını karşılaştırdığım Tablo 1 yukarıdaki iddiayı güçlendirmektedir. Bu dört gazeteyi seçmemin iki ana sebebi var. Birincisi, bu dört gazete farklı kesimlerde yer alan ve sayıları milyonlar ile ifade edilebilecek oldukça geniş kitlelere hitap etmektedirler. İkincisi ise sahip oldukları teknik altyapı sayesinde Zaman, Hürriyet ve Sabah gazetelerinde 1997 y1lına kadar, Milliyet'te ise 2001 yılına kadar geriye dönük araştırma yapılabilmektedir. 


\begin{tabular}{|l|c|c|c|c|}
\hline \multicolumn{5}{|l|}{$\begin{array}{l}\text { Tablo 1. Dört Kitle Gazetesinde "Laik-Laiklik-Laikleşme" kavramları ile } \\
\text { “Seküler-Sekülerlik-Sekülerleşme" kelimelerinin kullanım sıklı̆ı }\end{array}$} \\
\hline & $\begin{array}{c}\text { Zaman } \\
\text { (Ocak 1997 } \\
\text { Nisan 2014) }\end{array}$ & $\begin{array}{c}\text { Hürriyet } \\
\text { (Ocak 1997 } \\
\text { Nisan 2014) }\end{array}$ & $\begin{array}{c}\text { Sabah } \\
\text { (Ocak 1997 } \\
\text { Nisan 2014) }\end{array}$ & $\begin{array}{c}\text { Milliyet } \\
\text { (Ocak 2001 } \\
\text { Nisan 2014) }\end{array}$ \\
\hline $\begin{array}{l}\text { Laik- } \\
\text { Laiklik- } \\
\text { Laikleşme }\end{array}$ & $24463 \mathrm{kez}$ & $19340 \mathrm{kez}$ & $4389 \mathrm{kez}$ & $11628 \mathrm{kez}$ \\
\hline $\begin{array}{l}\text { Seküler- } \\
\text { Sekülerlik- } \\
\text { Sekülerleşme }\end{array}$ & $1642 \mathrm{kez}$ & $369 \mathrm{kez}$ & $254 \mathrm{kez}$ & $272 \mathrm{kez}$ \\
\hline
\end{tabular}

Türkiye gündemini -tarihsel süreçlerden dolay1- sekülerleşme kelimesinden daha çok laiklik kelimesinin meşgul etmesi anlaşılabilir olsa da kelimelerin kullanılma sıklığı 24463'a 1642 ise (Zaman gazetesi) ya da 19340'a 369 (Hürriyet gazetesi) ise bu rakamları açıklamak için Türkiye'nin siyasi tarihinden ve bir kelimenin anayasaya girmiş olmasından daha farklı bir dinamiğe ihtiyaç duyulmaktadır. Zira toplum-din ilişkisine dair bir açıklama olan sekülerleşme kavramının Türkiye'de çok kullanılmıyor olmasının altında Türkiye kamuoyunun bu konuya olan ilgisizliği yatmamaktadır. Aksine, uzun yıllar Türkiye gündeminin en önemli maddelerinden biri olan "muhafazakârlaşma", "Malezyalılaşma" ya da "İranlaşma" gibi tartışmalar aslında sekülerleşme kavramının tam da merkezde olduğu tartışma konularıdır. Ancak ne yazık ki, bu tartışmalarda dahi laik, laiklik, laikleşme gibi kelimeler çoğu zaman yanlış anlamlar taşıyarak seküler, sekülerlik ya da sekülerleşme kavramları yerine kullanıldılar.

Medya gibi, Türkiye'deki akademi dünyası da henüz iki kavram arasındaki farkı yeterince içselleştirememiş görünmektedir. Örneğin, Duran (1995) laikleşme ile sekülerleşmeyi hem birbirlerinin yerine kullanıyor hem de sekülerleşmeyi -öyle olmamasına rağmen- "birilerini bir şeylerden kurtarma, arındırma, bağımsızlaştırma” gibi bir projenin parçası olarak görüyor:

“Laikleşme (sekülerleşme); insan aklı ve düşüncesiningenel olarak-dini ve metafizik denetimden kurtarılma- 
s1 süreci olarak tanımlanabilir. Toplumsal hayatın tüm branşlarının; siyasetin, kültürün, bilimin dine dayanan değerlerden arındırılması ve bağımsızlaştırılması olay1dir" (29-30).

Sosyolog Akşit (2005) İletişim Yayınları'ndan çıkan Şerif Mardin'e Armağan adlı kitapta "Laikleşme Tipolojisi ve Türkiye'de Laiklik Deneyimi”" adlı makalesinde şu ifadelere yer veriyor:

"Laikleşme kuramını Protestanlığın dişındaki Katolikliğin geçirdiği tarihsel süreçler açısından sorgulayan ve yeniden formüle eden [José] Casanova (1994) İslamiyet'in laikleşme ile olan ilişkisini araştırmamızı... Casanova'ya göre (1994), bir ülkenin veya toplumun laikleşmiş olduğunu söylediğimiz zaman üç farklı boyutta değerlendirme yapıyoruz: farklılaşma, özel alana çekilme ve dinselliğin azalmas1 (...)" (68).

Ancak Casanova'nın 1994 y1lında basılan Public Religions in Modern World kitabında geçen ifadeler ile Akşit'in kitaptan aktardığ1 ifadeler ile aynı değil. Casanova laikleşmeden değil, sekülerleşmeden bahseder ve kitabında sekülerleşme teorisinin temel argümanını tartışır. Casanova (1994: 19) Three Separate Moments of the Theory of Secularization" alt başlığını kullanırken, Akşit bunu "laikleşmenin üç farklı boyutu" diye çeviriyor. Casanova'nın neredeyse kitabın tamamına hakim olan ifadesi "the theory of secularization" iken Akşit onu laikleşme olarak kendi makalesine aktarıyor.

Ayrıca, Giddens (2006/2012)'ın Türkiye'deki üniversitelerde sosyolojiye giriş dersi olarak okutulan Sosyoloji kitabının İngilizce orijinalinde "secularization" olarak geçen alt başlık, Türkçe basıma "laikleşme" diyerek çevrilmiş durumdadır.

Sekülerizm ise dinden uzak bir yapıyı hem devlet hem de birey için olumlayan, bunu savunan, daha iyi bir dünya için sekülerleşmek gerektiğini iddia eden ideolojinin ismidir. Hâlbuki sekülerleşme tezi bu tarz iddiaları dillendirmemektedir. Aksine, sekülerleşme tezinin en 
ünlü savunucularından Bruce (2002: 38) sekülerleşmenin bir toplumun daha sofistike, akıllı, olgun, bilgili olduğu için ortaya çıkmadığını, ya da sekülerleşmenin ille de daha iyi bir hayatın kapısını açmayacağını belirtir.

$\mathrm{Bu}$ örneklerden de anlaşılacağı gibi, Türkiye'deki bazı akademisyenler ve gazeteciler, laiklik ve sekülerleşme kavramlarını kimi zaman anlaşılır sebeplerle kimi zaman ise biraz zorlayarak aynı anlamda kullanmaktadırlar. Ancak, bu iki kavramı, ifade ettikleri farklı şeyler nedeni ile birbirilerinin yerine kullanmamak gerekmektedir. Zira az sonra aşağıda ifade edileceği gibi, laik olmayan devletlerin seküler yaşam tarzına sahip bireyleri ya da toplumları olduğu gibi, laik devletlerin oldukça dindar, deseküler bireyleri ya da toplumları olabilir.

\section{Devletler ve İnanç Konusunda Onlardan Farklı Toplumları}

En geniş anlamı ile laiklik, din ve devlet arasındaki ilişkiye, sekülerleşme ise din ve toplum arasındaki ilişkiye dairdir. Zira laik devletlerin seküler olmayan toplumları ya da laik olmayan devletlerin seküler yaşam tarzına sahip toplumları olabilir. Amerika Birleşik Devletleri'nde George Washington, Thomas Jefferson, Benjamin Franklin gibi kurucu babalar henüz ülke kurulurken din ve devlet işlerini birbirinden ayırmış ve yeni dünyayı din özgürlügü üzerinde temellendirmişlerdi (İmga, 2010). Ancak ABD'de devlet inançlara karşı olumlu ya da olumsuz herhangi bir pozisyon almazken Amerika'nın kendine özgü dinamiklerinden dolayı toplumun dini hassasiyetleri oldukça yüksek ve kiliselere gitme oranları aynı modernliğe sahip diğer Avrupa ülkelerinden fazladır (Berger, 2008; Casanova, 2007). Bunun yanında İran İslam Cumhuriyeti 1979'dan beri şeriat ile yönetilmesine rağmen toplumun azımsanmayacak kadar ciddi bir çoğunluğu seküler yaşam tarzına sahiptir. Kazemipur ve Rezaei (2003: 357)'nin yaptığı araştırmalar İran toplumunun son 30 senede devleti kadar kendisini dindarlaştıramadığını ortaya koymaktadır. İranlılar devlet izin vermediği için başlarını kamusal alanda açamıyorlar, dışarıda içki içemiyorlar ve hukuksal olarak da dini kanunlar altında yaşamak zorunda kalıyorlar. Ancak devletin olmadığı noktalarda -özellikle evlerinin içinde- seküler yaşam tarzlarına sahipler. İran ev partileri (başka yerde parti yapma şansları olmadığı için) kadınların göğüs dekolteli, kadınlık hatlarını ortaya koyan kıyafetler giydiği, alkol tüketilen, kadın ve erkeğin devletin 
onlara dayattığı dini kanunlardan özgür olduğu yerlerdir (Farid, 2013; Maxfux, 2013). ${ }^{7}$ Birçok İranlı kadının başını kapatmasının sebebi dindar olmalarından kaynaklanmamaktadır. Devletin vereceği cezalardan dolayı seküler tarzlarını devletin görmeyeceği veya göremeyeceği yerlerde yaşamaları gerekmektedir. İran'ı silah ile yöneten dini bir rejimin, pekâlâ seküler yaşam tarzına sahip bir halkı olabilir. Devletin laik olmaması, şeriat ilkeleri ile yönetiliyor olması İranlıları daha fazla dindar yapmiyor, sadece kamusal alanda zorla dindar görünmek zorunda kalıyorlar.

Türkiye bu noktada ilginç bir örnek olarak karşımıza çıkıyor. Özellikle 20. yüzyıl boyunca dışlayıcı laiklik ya da hegemonik sekülerizm ile yönetilen bir toplum, bu süreçte devleti kadar kendisini dinden soyutlayamadı. Atatürk ve diğer yönetici elitler saltanatı ve halifeliği kaldırarak, insanların şapkalarını ve giyim kuşamlarını değiştirerek, tekke, zaviye ve türbeleri kapatarak, halkın yazı dilini değiştirerek toplumu sekülerleştirebileceklerini düşünmüşlerdi. Ancak devleti laik hale getirmek anayasaya eklenecek bir hükümle mümkün iken, dinin toplumsal hayattaki varlığını azaltmaya çalışmak yukarıdan dayatılarak kolayca ulaşılabilecek bir süreç değildir. Kanun değişikliliği ile toplumlar sekülerleşebilselerdi, aynı şekilde bir kanunla o sekülerliğin yok olması gerekirdi. Toplumların sekülerleşmesi, devletlerin laikleşmesi gibi kanunla olacak, belli bir projenin içerisinde gerçekleşebilecek bir şey değildir. O nedenle ifade edilmeli ki, Türkiye laik bir devlet olarak kurulmaya çalışılmış olsa da 1930'ların yönetici elitlerinin çıkardığı yasalar -aynen İran'da yaşandığı gibi- uzunca bir müddet halkın kendi dinsel yaşamını devletin göremeyeceği yerde sürdürmesine neden oldu.

$\mathrm{Bu}$ makale laiklik ile sekülerleşme kavramları arasında hiçbir şekilde etkileşim olmadığını iddia etmemektedir. Muhakkak ki İran'ın bir din devletine dönüşmesi belli bir grubun daha dindarlaşmasına, Türkiye'nin dışlayıcı laiklik anlayışı da belli bir grubun sekülerleşmesine neden olmuştur. Ancak, ne İran yasalarla halkını desekülerleştirme konusunda çok başarılı oldu, ne de Türkiye jakobenist yasalarla

7 İnternetteki video sitelerinde "Tahran Nights" diye aratıldığı vakit yeterince örnek ile karşılaşılacaktır. 
halkını dinden uzaklaştırabildi. Zira bu süreçler için yani sekülerleşme ya da desekülerleşme süreçleri için yasa koyucudan çok daha fazlasına ihtiyaç var.

\section{Sonuç}

Söz konusu ülke Türkiye ise, sekülerleşme kavramı yeni yeni kendisine alan yaratmaya çalışıyor denilebilir. Bu makalenin amacı da sekülerleşme kavramının ne demek olduğunu detaylıca anlatıp, onun çokça karıştırıldığı laiklik kavramı ile farkını ortaya koymaktı. Belli bir zaman dilimi içerisinde, dinin ya da metafiziksel dünyanın toplumsal düzeydeki prestijlerinin ve topluma etki etme güçlerinin göreceli olarak azalması demek olan sekülerleşme ile dinin devlet mekanizmalarından uzaklaştırılmasının ifadesi olan laiklik kavramlarının daha uzun yıllar Türkiye'de birbirlerinin yerine kullanılacağını düşünülse de, son zamanlarda kullanım konusundaki hassasiyetin arttığına tanık olunmaktadır. Zira Türkiye toplumu için din her geçen gün sosyal hayattan daha fazla çekilirken, dinin, dinimsi yapıların ve batıl inançların gücü ve prestiji azalırken, yeni kuşakların günlük aktivitelerinde ya da gelecek ile ilgili planlarında bu bahsi geçen dinamikler kendilerine daha az yer buluyorken bu konularda yapılacak tartışmalar "laiklikmuhafazakârlık" sığ ekseninden çıkmaz zorunda kalacak gibi görünmektedir. 


\section{Kaynakça}

AKŞİT, B. (2005) Laikleşme Tipolojisi ve Türkiye'de Laiklik Deneyimi. ÖNCÜ, A. ve TEKELIOĞLU, O. (der.) Şerif Mardin'e Armağan, İstanbul: İletişim Yayınları.

ARMAĞAN, M. (1997, 26 Eylül), Sekülarizasyon (Laikleşme) Efsanesi. Zaman Gazetesi.

AQUAVIVA, S. S. (1960) The Psychology of Dechristianisation in the Dynamics of the Industrial Society. Social Compas.[Online] 7(3). s. 209-225. http://scp.sagepub.com.proxy.ubn.ru.nl/ content/7/3/209.full.pdf + html. [Erişim Tarihi: 23.01.2013].

BAŞDEMİR, H. Y. (2011) Optimum Değerler Olarak Laiklik ve Din Özgürlüğü.

BAŞDEMİR, H. Y. (der.) Türkiye'de Din Özgürlüğü ve Laiklik, Ankara: Liberte Yayınları.

BERGER, P., DAVIE G. ve FOKAS E. (2008) Religious America, Secular Europe? A Theme and Variations, Burlington: Ashgate Publishing Company.

BRUCE, S. (1999) Modernisation, Religious Diversity and Rational Choice in Eastern Europe. Religion, State and Society. [Online] 27 (3-4). s. 265-275. http://www.tandfonline.com.proxy.ubn. ru.nl/doi pdf/10.1080/096374999106476. [Erişim Tarihi: 09.10.2012]

BRUCE, S. (2002) God is Dead. Oxford: Blackwell Publishing.

BRUCE, S. (2003) The Social Process of Secularization. FENN, R. K. (der.) The Blackwell Companion to Sociology of Religion, Oxford: Blackwell Publishing.

BRUNNER, J. (1991) From Rousseau to Totalitarian Democracy: The French Revolution in J. L. Talmon's Historiography. History and Memory. [Online] 3(1) s. 60-85. http://www.jstor.org.proxy. ubn.ru.nl/stable/pdfplus/25618611.pdf?acceptTC=true\&jpdCon firm=true. [Erişim Tarihi: 04.04.2013]

CASANOVA, J. (1994) Public Religions in the Modern World. Chicago: The University of Chicago Press.

CASANOVA, J. (2007) Immigration and the New Religious Pluralism: 
A European Union / United States Comparison. BANCHOFF, T. (der.) Democracy and The New Religious Pluralism. Oxford: Oxford University Press.

COX, H. (1965) The Secular City. New York: Pelican.

DAVIE, G. (1990) Believing without Belonging: Is this the Future of Religion in Britain. Social Compass. [Online] 37(4). s. 455469. http://scp.sagepub.com.proxy.ubn.ru.nl/content/37/4/455. [Erişim Tarihi: 22. 10.2012]

DAVIE, G. (1994) Religion in Britain Since 1945: Believing Without Belonging, Blackwell, Oxford.

DURAN, B. (1995) Sekülerleşme-Laikleşme Süreci ve Gezegen Ölçeğinde Sonuçları. Köprü Dergisi. [Online] 95 Yaz, No.51. http://www.koprudergisi.com/index.asp?Bolum=EskiSayilar\& Goster=Yazi\&YaziNo=215 [Erişim Tarihi: 17.01 .2012$]$

ERTIT, V. (2013) Sekülerleşme Teorisi. Muhafazakar Düşünce Dergisi. 10 (3). s. 207-229.

FARID, M. (2013, 19 May1s), "What part of Public Diplomacy don't you understand?", US Public Diplomacy Blogspot [Online] http://uspublicdiplomacy.blogspot.com/2013/05/what-part-ofpublic-diplomacy-dont-you.html. [Erişim Tarihi: 25.07.2013]

FENN, R. K. (1969) The Secularization of Values: An Analytical Framework for the Study of Secularization. Journal for the Scientific Study of Religion. [Online] 8(1). s. 112-124. http:// www.jstor.org.proxy.ubn.ru.nl/stable/pdfplus/1385259.pdf?\&ac ceptTC $=$ true \&jpdConfirm $=$ true. [Erişim Tarihi: 21.08 .2011$]$

GIDDENS, A. (2006) Sociology. $5^{\text {th }}$. Edition. Cambridge: Polity Press.

GIDDENS, A. (2012) Sosyoloji. İstanbul: Kırmızı Yayınları.

GÖLE, N. (1997) Secularism and Islamism in Turkey: The Making of Elites and Counter-Elites. Middle East Journal. [Online] 51(1). s. 46-58. https://www.academia.edu/3662578/ The_Secularism and_Islamism_in_Turkey_The_Making_of_Elites_and_ Counter-Elites.[Erişim Tarihi: 08.04.2013]

HANSON, S. (1997) The Secularization Thesis: Talking at Cross Purposes. Journal of Contemporary Religion. [Online] 12(2). 
s. 159-179. http://www.tandfonline.com.proxy.ubn.ru.nl/doi/ pdf/10.1080/13537 909708580797. [Erişim Tarihi: 01.03.2011]

HERBERG, W. (1962) Religion in a Secularized Society: The New Shape of Religion in America (Lecture I). Review of Religious Research. [Online] 3 (4). s. 145-158. http://www.jstor.org.proxy. ubn.ru.nl/stable/pdfplus/3510445.pdf?acceptTC=true\&jpdConf irm=true. [Erişim Tarihi: 12.11.2012]

İMGA, O. (2010) Amerika'da Din ve Devlet. Ankara: Liberte Yayınlar1.

İNCE, Ö. (2012, 4 Mart). Laikleşme Süreci Dindarlaşma Süreci. Hürriyet Gazetesi.

KARAKAS, C. (2007). Turkey: Islam and Laicism Between the Interest of State, Politics, and Society. Peace Research Institute Frankfurt Reports. [Online] No. 78, s. 1-40. http://www.hsfk.de/ downloads/prif78.pdf. [Erişim Tarihi: 03.04. 2010]

KAZEMIPUR, A. ve REZAİ, A. (2003) Religious Life under Theocracy: The Case of Iran. Journal for the Scientific Study of Religion. [Online] 42(3). s. 347-361. http://www.jstor.org. proxy.ubn.ru.nl/stable/pdfplus/1387739.pdf?\&acceptTC=true\& jpdConfirm=true. [Erişim Tarihi: 07.07.2013]

KÖSE, A. (Der.) (2002). Sekülerizm Sorgulanıyor. İstanbul: Ufuk Kitaplar1.

KURU, A. (2007) Passive and Assertive Secularism: Historical Conditions, Ideological

Struggles, and State Policies toward Religion. World Politics. [Online] 59(4). s. 568-594.http://www.jstor.org.proxy.ubn.ru.nl/ stable/pdfplus $/ 40060173$.pdf?acceptTC $=$ true $\&$ jpdConfirm $=$ tru e.[Erişim Tarihi: 06.07.2012]

KÜÇÜK, A. (2011) Laikliğe İlişkin Tartışmalar ve İki Laiklik Modeli. BAŞDEMIR,

H. Y. (der.) Türkiye’de Din Özgürlüğü ve Laiklik. İstanbul: Liberte Yayınları.

LECHNER, F. L. (1991) The Case against Secularization: A Rebuttal. Social Forces [Online] 69(4). s. 1103-1119. http:// web.b.ebscohost.com.proxy.ubn.ru.nl/ehost/pdfviewer/ 
pdfviewer?sid=df4fd854-681b-4c5e-acf7-d7dcd4fee $26 \mathrm{f} \% 40$ ses sionmgr110\&vid=2\&hid=124. [Erişim Tarihi: 14.03 .2012 ]

MOHANTY, M. (1989) Secularism: Hegemonic and Democratic. Economic and Political Weekly. [Online] 24(22). s 1219-1220. http://www.epw.in/perspectives/secularism-hegemonic-anddemocratic.html. [Erişim Tarihi: 09.09.2011]

MAXFUX (2013), "Iran Which We don't Know". [Online] http:// maxfux.livejournal.com/265190.html. [Erişim Tarihi: 11.10. 2013]

MERT, N. (2009, 23 Mart) Zenginleştikçe Laikleşiyorlar mı? Hürriyet Gazetesi.

MISES, L. (1981) Socialism, An Economic and Sociological Analysis, Indianapolis: Liberty Fund.

ÖZDEN, M. (2005) Müslüman Kelamında Sekülerleşme Süreci. (Yayınlanmamış doktora tezi), Ankara Üniversitesi, Sosyal Bilimler Enstitüsü. http://acikarsiv.ankara.edu.tr/eng/ browse/1547/. [Erişim Tarihi: 24.06. 2011]

STIRLING, P. (1958) Religious Change in Republican Turkey. The Middle East Journal. [Online] 12(4). s. 395-408. http:// search.proquest.com.proxy.ubn.ru.nl/docview/1290780092/ fulltextPDF/E09A7E6C01B24F1CPQ/67?accountid=11795. [Erişim Tarihi: 14.02.2013]

SOUVAY, C. L. (1923) The French Papal States during the Revolution. The Catholic Historical Review. [Online] 8(4). s. 485-496. http:// search.proquest.com.proxy.ubn.ru.nl/docview/1290055122/ fulltextPDF/4B4DFC6E7B1E4EE1PQ/4?accountid=11795. [Erişim Tarihi: 05.02.2012]

WEBER, M. (2001). The Protestant Ethic and The Spirit of Capitalism. PARSONS, T. (çev.) London: Routledge.

WILSON, B. R. (1969). Religion in a Secular Society: a Sociological Comment, London: Watts.

WILSON, B. R. (1979) The Return of the Sacred. Journal for the Scientific Study of Religion. [Online] 18(3). s. 268-280. http:// www.jstor.org.proxy.ubn.ru.nl/stable/pdfplus/1385653.pdf?\&ac ceptTC $=$ true \&jpdConfirm $=$ true. [Erişim Tarihi: 02.01.2010] 